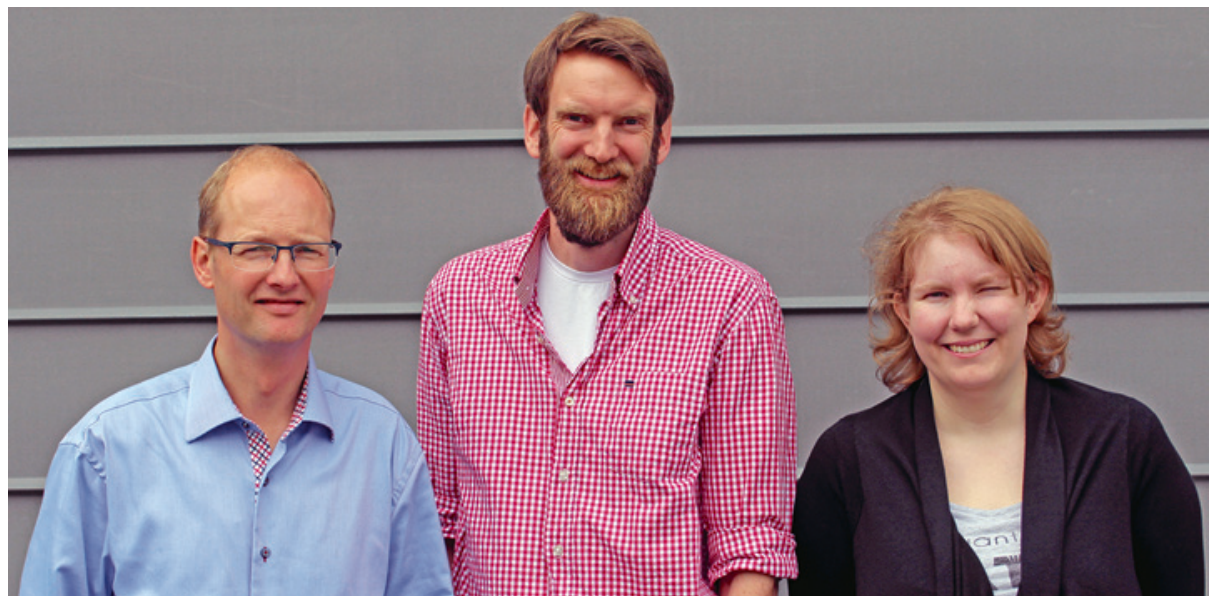

De norske bidragsyterne til studien. Frå venstre: Gunnar Mellgren, Simon Dankel og Christine Haugen. Foto: Jan-Inge Bjune

\section{Feittceller har ein brytar for forbrenning}

Feittceller har ein molekylær brytar som avgjer om dei lagrar eller

forbrenn energi. Dette viser ein studie med norske bidrag.

I ein studie som er publisert i New England Journal of Medicine, har eit internasjonalt forskarteam med deltaking frå bl.a. Universitetet i Bergen funne ein molekylær «brytar» som styrer om feittceller lagrar eller forbrenn energi (1). Brytaren er genetisk betinga; $44 \%$ av europearar har redusert evne til å skru på forbrenninga ved å lage såkalla beige feittceller. Beige feittceller omdannar kjemisk energi (ATP) til varme gjennom termogenese, som er styrt av bl.a. proteinet UCP1. Denne studien viser no at dette kan vere fysiologisk relevant i vaksne menneske.

Utgangspunktet for studien var den sterkaste assosiasjonen som er funne mellom genetisk variasjon og overvekt i genomvide assosiasjonsstudiar (GWAS), der genvariantar i FTO-genområdet gir 1-4 kg auka kroppsvekt i store befolkningsstudiar. Med nye sofistikerte metodar for å undersøke funksjonar i DNA, blant anna med samanlikning av epigenetisk status i 127 ulike typar celler og vev, vart det påvist at ein bestemt FTO-genvariant, rs1421085 TT $\rightarrow$ $\mathrm{CC}$, gjer at proteinet ARID5B ikkje greier å skru av uttrykket av genane IRX3 og IRX5. Auka uttrykk av desse genane endrar programmeringa tidleg i utviklinga av nye feittceller, slik at feittcellene i større grad programmerast til å lagre energi framfor å kvitte seg med ekstra energi som varme.

I studien brukte forskarane blant anna den nye teknikken for genmanipulering, CRISPR-Cas9, for å direkte påvise i menneskeceller at endring av eitt einaste basepar på den bestemte staden i DNA (TT $\rightarrow$ CC av rs1421085-varianten) påverkar energibalansen.

- Med denne studien har vi funne ein ny molekylær mekanisme som det kanskje kan bli mogleg å rette seg mot med medikamentell behandling av overvekt, seier andreforfattar Simon Dankel, som er postdoktor i Bergen. -Ved å manipulere genane og proteina som er involverte i denne nye brytarmekanismen, kan ein tenke seg at ein kan skru på varmeproduksjonen som ei ekstra hjelp til å motverke overvekt i befolkninga.

- Meir generelt illustrerer studien korleis vi no kan finne ut kva som skjer i andre genområde som genomvide assosiasjonsstudiar har knytt til folkesjukdomar som type 2-diabetes, hjartesjukdom, Alzheimers sjukdom og astma, seier Dankel.

\section{Møttest på kongress}

Det norske bidraget til studien er ved postdoktor Simon Dankel, doktorgradsstipendiat Christine Haugen og Gunnar Mellgren, professor ved Universitetet i Bergen og klinikkdirektør ved Haukeland universitetssjukehus. Forskingsgruppa er knytt til Hormonlaboratoriet ved Haukeland og KG Jebsen senter for diabetesforsking. Prosjektet har vore eit samarbeid med Melina Claussnitzer ved Universitetet i München og andre forskarar frå Tyskland, USA, Sverige og Canada. Dankel og Claussnitzer møttes på ein kongress om fedme i Istanbul i 2011 og har sidan arbeidd tett for å forstå korleis genvariantar ved fedme og type 2diabetes påverkar funksjonen til feittceller.

\section{Martine Rostadmo}

Tidsskriftet

\section{Litteratur}

1. Claussnitzer M, Dankel SN, Kim KH et al. FTO Obesity Variant Circuitry and Adipocyte Browning in Humans. N Engl J Med 2015; 373: 895-907.
Ordforklaringar

Genvariant: Forskjell i ein bestemt nukleotid/ basepar i DNA mellom ulike personar, til dømes at delar av befolkninga har baseparet TT og andre har CC på ein spesifikk koordinat i DNA. Dei fleste genvariantar i befolkningsstudiar (93\%) ventast å påverke i kva grad genar i det aktuelle DNA-området vert avlest.

Genavlesing: Alle celler i kroppen brukar DNA som ein kode som kan lesast av etter behov. Dette skjer ved at bestemte protein lagar kjemiske bindingar med DNA, slik at enzym som lagar kopiar av DNA-sekvensen blir aktivert. Desse DNA-kopiane (RNA) blir så til protein som utøver funksjonar i cellene, som til dømes kva som skal skje med ekstra energi.

Termogenese: Omdanning av kjemisk energi (ATP) til varme i mitokondriane, slik at energien blir frigjort i staden for å bli brukt til oppbygging av celler/feittlagring. Dette skjer blant anna i beige og brune feittceller, til forskjell frå kvite feittceller som har færre mitokondriar.

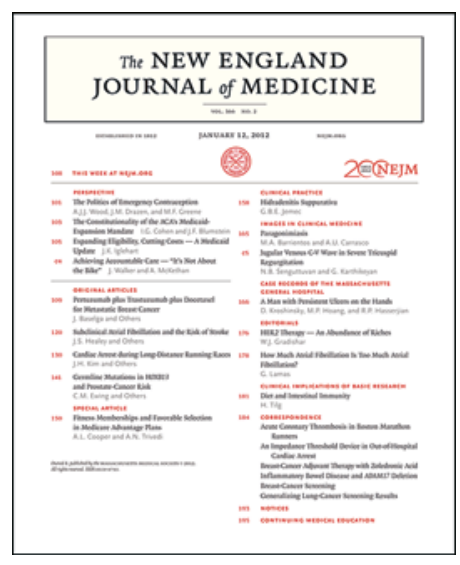

Artikkelen vart publisert i New England Journal of Medicine i september 2015 